\title{
Distribution of Some Risk Factors Related to Soft Tissue Injuries in Dentoalveolar Traumas
}

\author{
Dento Alveolar Travmalarda Görülen Yumuşak Doku \\ Yaralanmalarıyla Bağlantıı Risk Faktörlerinin Dağılımı \\ (D) Fatih Şengül ${ }^{1}$, (1) Hüseyin Şimşek ${ }^{2}$ \\ ${ }^{1}$ Atatürk University Faculty of Dentistry, Department of Pedodontics, Erzurum, Turkey \\ ${ }^{2}$ Ordu University Faculty of Dentistry, Department of Pedodontics, Ordu, Turkey
}

Keywords

Tooth injuries, soft tissue injuries, child

Anahtar Kelimeler

Diş yaralanmaları, yumuşak doku

yaralanmaları, çocuk

Received/Geliş Tarihi : 26.02.2017

Accepted/Kabul Tarihi : 08.05.2017

doi:10.4274/meandros.69188

Address for Correspondence/Yazışma Adresi: Hüseyin Şimşek MD,

Ordu University Faculty of Dentistry,

Department of Pedodontics, Ordu, Turkey

Phone : +90 5385845745

E-mail : dr.huseyinsimsek@gmail.com

ORCID ID: orcid.org/0000-0002-9868-8266

(C) Meandros Medical and Dental Journal, Published by Galenos Publishing House.

This is article distributed under the terms of the

Creative Commons Attribution NonCommercial 4.0

International Licence (CC BY-NC 4.0).

\begin{abstract}
Objective: Treatment failures in soft tissue injuries may result in economic, psychological, and esthetic problems. The aim of this study was to investigate the presentation of soft tissue injuries in dento-alveolar traumas.

Material and Methods: The data were obtained from 268 children aged 1-15 years who were referred to a pedodontics clinic within one week of experiencing dental trauma during 2010-2015. The criteria used to categorize the data obtained from the dental trauma records were gender, age, localization (lips, gingiva, cheeks, tongue, and perioral tissues), wound type (abrasion, laceration, contusion, and mixed), time elapsed to treatment of the injury, and classification of the dentoalveolar trauma.

Results: Soft tissue trauma was noted in $90(33.6 \%)$ children. There was no statistically significant difference between the patients according to gender, age, and the time elapsed between the injury and treatment. With regard to the type of soft tissue trauma, $18.9 \%$ were contusions, $7.8 \%$ were abrasions, $43.3 \%$ were lacerations, and $30 \%$ were mixed injuries. Soft tissue injuries were frequently (64.4\%) accompanied by periodontal injuries.

Conclusion: Soft tissue injuries are occasionally seen in dento-alveolar traumas. Within the limits of this study, the type, localization, and classification of the trauma were more important factors than gender in soft tissue injuries.
\end{abstract}

Öz

Amaç: Yumuşak dolu yaralanmalarında görülen tedavi başarısızlıkları ekonomik, psikolojik ve estetik problemlerle sonuçlanabilmektedir. Biz bu çalışmayla diş-alveol travmalarında görülen yumuşak doku yaralanmalarını incelemeyi amaçladık.

Gereç ve Yöntemler: Veriler 2010-2015 yılları arasında diş travmasından dolayı 1 hafta içerisinde pedodonti kliniğine başvuran 1-15 yaş arasındaki 268 çocuk hastadan elde edildi. Diş travmasından elde edilen veriler cinsiyet, yaş, lokalizasyon (dudak, diş eti, yanak, dil ve periodontal dokular), yaralanma tipi (abrazyon, laserasyon, kontüzyon ve karışı), yaralanma ve tedavi arasında geçen zaman ve diş travma sınıflaması kriterleri kullanılarak kategorize edildi.

Bulgular: Tüm hastalardan $90(\% 33,6)$ hastada yumuşak doku yaralanması görüldü. Hastalarda yaş, cinsiyet, yaralanma ve tedavi arasında geçen zaman açısından istatistiksel olarak bir farklıık gözlenmedi. Yumuşak yaralanma tipine bakıldığında 
kontüzyon \%18,9, abrazyon \%7,8, laserasyon \%43,3 ve karışık \%30 oranında görüldü. Yumuşak doku yaralanmaları sıklıkla (\%64,4) periodontal yaralanmalarla birlikte görüldü.

Sonuç: Dental travmalarda yumuşak doku yaralanmaları sıklıkla görülmektedir. Bu çalışma sınırları içerisinde yumuşak doku yaralanmalarının lokasyonu, tipi ve travma sınıflaması gibi kriterler cinsiyete göre daha önemli bulunmuştur.

\section{Introduction}

The oral region accounts for as little as $1 \%$ of the total body size. However, injuries to this region account for $5-33 \%$ of all injuries among all ages $(1,2)$. Traumatic dental injuries often result in soft tissue injuries. Osunde et al. (3) observed soft tissue injuries in $70 \%$ of all patients with maxillofacial traumas. Díaz et al. (4) reported that $39 \%$ of dento-alveolar traumas were accompanied by soft tissue injuries. In spite of this fact, the soft tissue injuries might be exposed to ignorance by the dentists who primarily focus on the patients' traumatized teeth.

Soft tissue traumas are usually seen as abrasion (rubbing or scraping of the mucosa), contusion (a bruise caused by a blunt object), laceration (tear in mucosa), and rarely seen as penetration (produced by sharp object) and avulsion (loss of tissue) (2).

Inadequate emergency care of soft tissue injuries in dento-alveolar traumas may cause economic, psychological, and aesthetic problems (5). There is limited research on the relationship between soft tissue injuries and dento-alveolar traumas $(3,6)$. Although soft tissue injuries in children decrease with age, Osunde et al. (3), found out that this was not the case in dento-alveolar injuries (3).

The null hypothesis was that the soft tissue injuries in children, who referred to a pedodontics clinic with dento-alveolar traumas have no difference according to gender, age, localization (lips, gingiva, cheeks, tongue, and perioral tissues), wound type (abrasion, laceration, contusion, and mixed), time elapsed before treatment, and the relationship of these factors to the trauma classification.

\section{Material and Methods}

The study protocol was approved by the Ethics Committee of the Atatürk University Faculty of Medicine (reference number: 2013/40). A retrospective study was conducted in eastern Anatolia region, Turkey. The study included 268 records of patients (166 boys and 102 girls) aged 1-15 [8.19 \pm 3.90 standard deviation (SD)] with dento-alveolar traumas who were examined and treated for different injuries in the university dental clinic between April 2010 and July 2015. Of these 268 patients, only 90 had soft tissue injuries.

The inclusion criteria for this study were patients with dento-alveolar traumas who had presented to the clinic within seven days of the injury and who had not sought any dental treatment earlier. The exclusion criteria were dento-alveolar fractures with severe skeletal deformities in the head and neck region, and patients who had injured themselves after receiving local anesthesia.

The dento-alveolar trauma records included the patient's gender, age, affected dentition and localization (lips, gums, cheeks, palate, floor of the mouth, and tongue), classification of soft tissue injury (abrasion, laceration, contusion, and mixed), and the time interval between trauma and treatment. The dento-alveolar trauma was classified as injuries to the hard dental tissues and pulp, root fracture, injuries to the supporting tissues, and multiple injuries (7).

\section{Statistical Analysis}

Data analyses were carried out using SPSS software (SPSS for Windows, version 20.0, SPSS Inc., Chicago, IL, USA). Comparisons were performed with $X^{2}$ tests and the Mann-Whitney $U$ test, where appropriate, to investigate the association between various factors related to the dental trauma and the characteristics of the trauma. The comparisons were followed by logistic regression analyses of the dento-alveolar traumas impact on soft tissue injury types. The statistical significance level was set at $p<0.05$.

\section{Results}

In total, 268 children with dento-alveolar traumas presented to our clinic within one week of the injury [males, $n=166$ (61.9\%); females, $n=102$ (38.1\%)]. The percentage of soft tissue injuries in traumatic dental injuries experience was $31.9 \%$ in males and $36.3 \%$ in females. Therefore, females were found to be more prone to experience soft tissues injury in case of 
dento-alveolar trauma. Despite the numerical and proportional differences in the soft tissue traumas, there was no difference according to gender $\left(X^{2}=0.53\right.$, $\mathrm{p}=0.46)$.

There was no statistically significant difference $(p=0.32)$ in the mean age of the patients with soft tissue traumas $(7.87 \pm 3.69 \mathrm{SD})$ and the mean age of the remaining 178 children $(8.35 \pm 4.0 \mathrm{SD})$.

The null hypothesis was rejected. Soft tissue injuries were increased in the mixed dentition period (6-12 years) $(n=47)$, reaching the highest between the ages of 8 and 10 (Figure 1). The primary dentition period (0-6 years) was the next most common time of the injuries $(n=32)$. The incidence of soft tissue traumas decreased after the age of $12\left(X^{2}=17, p=0.36\right)$. The ratio of soft tissue injuries in the dento-alveolar traumas ranged between $21 \%$ and $83 \%$ according to age (Figure 2). The ratio was generally between 21$42 \%$ whereas, it was more than $50 \%$ for the ages of 4-6 years.

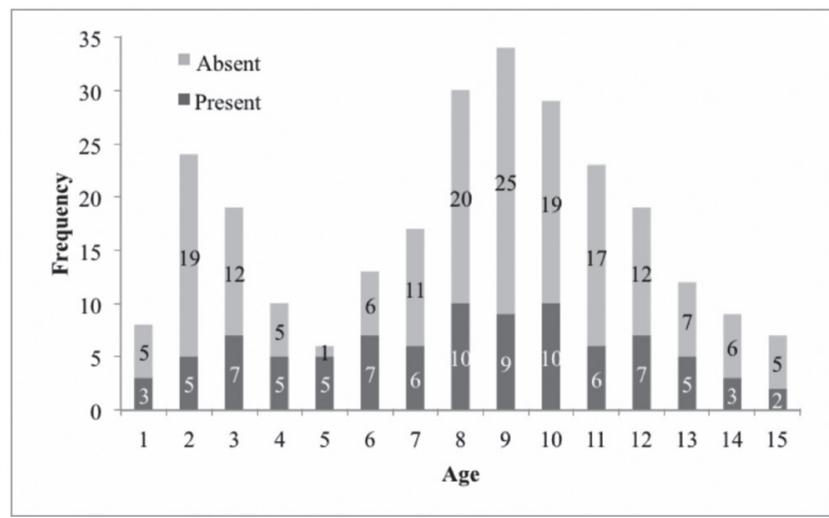

Figure 1. Frequency of the soft tissue injuries according to the age

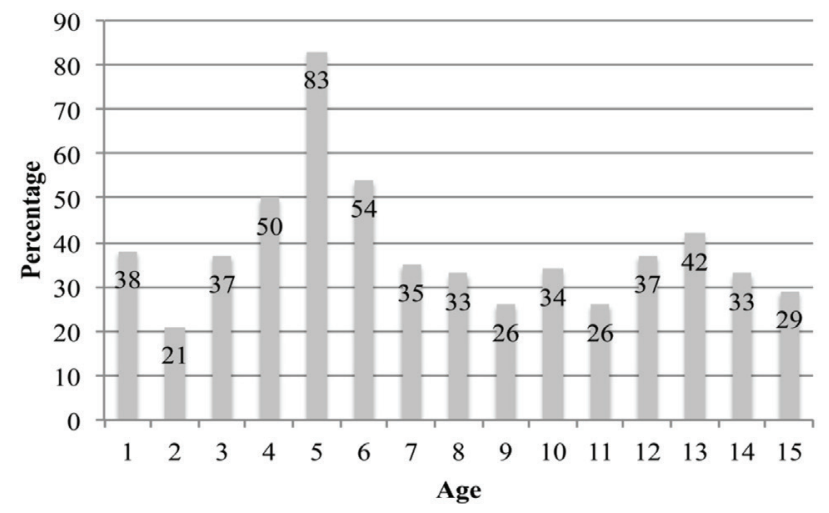

Figure 2. Distribution of the soft tissue injuries according to the age
The localization of the soft tissue injury types is shown in Figure 3. The frequencies of soft tissue injuries in children were $43.3 \%$ for lacerations, $30 \%$ for the mixed (more than one type of soft tissue injuries), $18.9 \%$ for contusions, and $7.8 \%$ for abrasions. Only, four patients with lacerations had penetration injuries. There was a statistically significant difference between the frequencies of abrasions and those of the other soft tissue injury types $\left(X^{2}=20.79, p=0.008\right)$. Most of the soft tissue injuries were in the maxilla ( $n=78,86.7 \%)$, followed by the mandible $(n=5,5.6 \%)$ and both jaws ( $n=7,7.8 \%)$. Also, the distribution of soft tissue injuries in the maxilla and mandible fits that of the injuries to the teeth $\left(X^{2}=3.84, p=0.045\right)$.

Figure 4 depicts the treatment times of the patients. Twenty-two (24.4\%) children with soft tissue injuries received treatment on the same day, 47 (52.2\%) in 2-3 days, and 21 (23.3\%) within 4-7 days. There was no statistically significant difference in the arrival times of the children with and without soft tissue injuries ( $p=0.401)$.

Figure 5 shows the association between the dentoalveolar trauma and the resultant wounds. Among

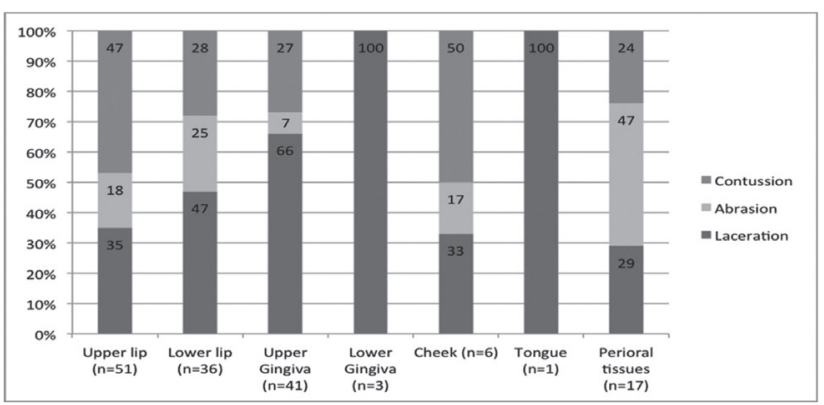

Figure 3. Distribution of the soft tissue injuries according to the localization

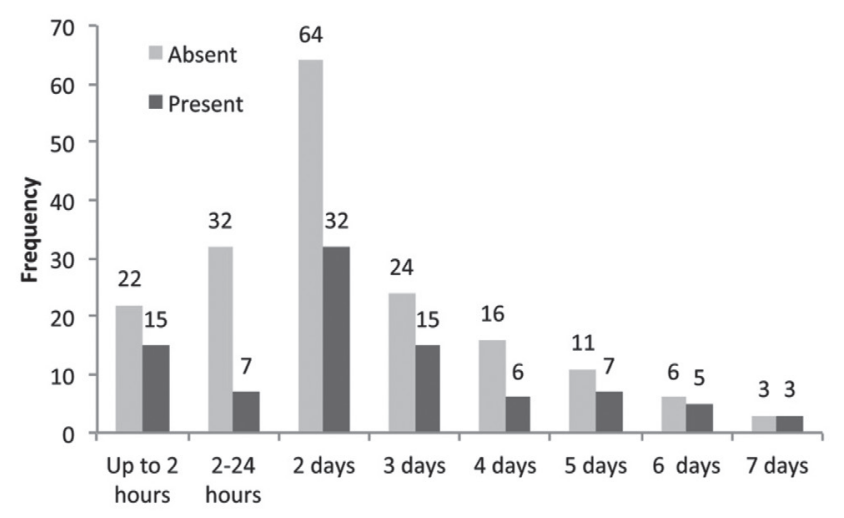

Figure 4. Time elapsed between the accident and seeking dental treatment 


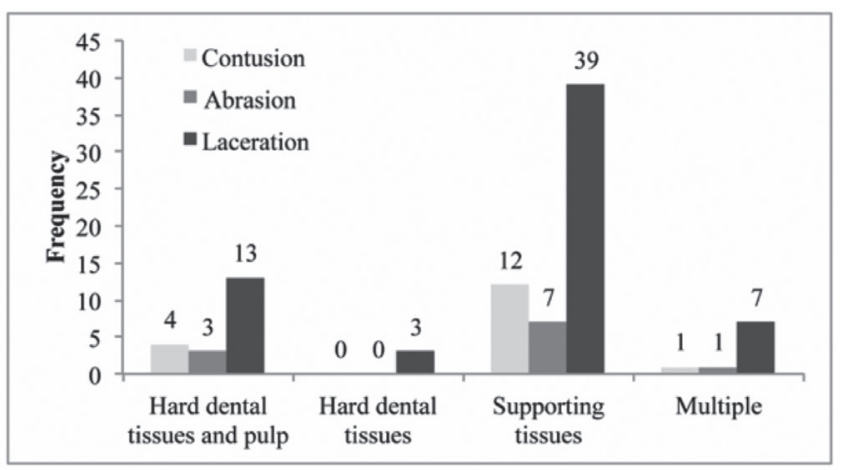

Figure 5. Distribution of the dento alveolar traumas according to wound type

the 90 patients with soft tissue injuries, 58 (64.4\%) had injuries to the supporting tissues, 20 (22.2\%) had hard dental tissue and pulp injuries, $9(10 \%)$ had multiple injuries, and 3 (3.3\%) had hard dental tissue injuries. There was a statistically significant difference in the soft tissue injuries, resulting from supporting tissue injuries ( $\left.p=0.001 X^{2}=15.72\right)$. Soft tissue injuries in the primary dentition were the consequence of supporting tissue injuries (84.8\%). And in the permanent dentition soft tissue injuries originated from supporting tissue injuries (52.6\%) and hard dental tissues and the pulp injuries (31.6\%).

\section{Discussion}

Traumatic dental injuries are usually accompanied by soft tissue injuries. In this study the soft tissue injuries in children were evaluated according to various factors. The null hypothesis was rejected. In our study, the frequency of soft tissue injuries was $33.6 \%$, which is similar to the distribution of dental injuries reported to be $30-50 \%$ in other studies $(1,4,8,9)$. Similar to our findings, many studies showed that males are more prone than females to dento-alveolar trauma $(10,11)$. However, we found no statistically significant difference in soft tissue injuries according to gender in common with other studies (12-15).

Although there was no statistically significant difference in age, the patients with soft tissue injuries were younger $(7.87 \pm 3.69 \mathrm{SD})$ than those without soft tissue injuries ( $8.35 \pm 4.0 \mathrm{SD})$. Severe trauma as a result of poorly developed defense mechanisms, muscle coordination, and motor skills may affect the frequency of soft tissue injuries in younger children (14-17). In our study, soft tissue injuries and dentoalveolar injuries were common in mixed dentition, with the highest frequency found in children aged 8-10 years. As reported in the literature, children aged 1-4 years are most susceptible (among all ages) to accidents and have the highest number of soft tissue injuries $(3,6,12,14,16,18)$. Studies have also reported that younger children who have a higher cranial vs. facial skeletal size, softer and more elastic bones, and protective thick soft tissues are more likely to be exposed to minor injuries, such as soft tissue injuries, whereas older children tend to be more susceptible to serious injuries $(6,17,19)$. Vuletić et al. $(20)$, found that soft tissue injuries peaked among preschool children aged two years (18). After the preschool period, the superego develops, and the child is exposed to disciplined training at school $(19,21)$. As reported in the literature, such training can decrease injury rates among those aged 4-6 years, even among children from disorganized families $(19,21)$. Nevertheless, in the present study, the highest percentage of soft tissue injuries in dento-alveolar traumas was observed among the children aged 4-6 years and particularly among those aged five years.

In dento-alveolar trauma, soft tissue injuries are seen most frequently in the maxilla, especially in the upper lip $(20,22)$. As reported in the literature, the high incidence of such injuries may be due to the protrusive structure of the maxilla $(4,11,13,21,23)$. In the present study, soft tissue injuries were most frequently found in the maxilla as previous studies.

Fractures of the molar teeth may be associated with traumatic injuries to the chin $(22,24)$. In our study only one patient had extrusive luxation and laceration on his permanent maxillary left first premolar caused by facial collision into a doorknob following slippage.

In studies of soft tissue injuries in maxillofacial and dento-alveolar trauma patients, lacerations accounted for $37.5-83.4 \%$, contusions accounted for $8.4-32.8 \%$, and abrasions accounted for 1.6$29.7 \%(4,6,13,15,23,25)$. Similarly, the frequency of lacerations in our study of soft tissue injuries was $43.3 \%$, whereas the frequency of mixed injuries, contusions, and abrasions was $30 \%, 18.9 \%$, and $7.8 \%$, respectively.

Abrasions are observed more commonly in perioral than intraoral tissues and are therefore less common than other types of injuries. A traumatic force with a high intensity, which could lead to dento-alveolar injury, may cause lacerations as the most frequent 
type of soft tissue injury $(24,26)$. Many lacerations resulting in swellings may be due to a combination of crushing and tearing of tissue. As noted in the literature, special attention should be paid to children with such injuries because healing occurs faster than in adults, resulting in the rapid formation of hypertrophic scars and keloids $(25,27)$.

In Eastern Anatolia Region, most emergency management of children's tooth injury trauma is undertaken by pediatric dentistry department. The most important principle in the treatment of soft tissue injuries is debridement of the wound and thorough cleaning with saline $(20,22)$. Lacerations were treated with suture. Antibiotics were prescribed, depending on the severity of the injury. If the patient has not received tetanus prophylaxis in the previous five years, patients were referred to hospital for additional doses $(25,27)$.

After the occurrence of soft tissue injury, new tissue formation lasts between 4-30 days $(10,26)$. Meanwhile, relatively simple soft tissue injuries, including contusion, heals within one week $(11,27)$. For this reason, the dento-alveolar trauma patients who were admitted within one week, were included in this study. Also, there was a statistically significant difference in the arrival time of the children with and without soft tissue injuries. Vuletić et al. (20) reported that children with soft tissue injuries presented earlier for dental treatment (18). However, there was no difference in the presentation time of those with soft tissue injuries in our study. With regard to the presentation time for dental treatment, the majority of the children with soft tissue injuries presented on the second day after the injury, followed by the first and third post-injury days. Among the patients who sought treatment within the first 24 hour, the frequency of those who presented within 2 hour of the injury may be explained by the sensitivity of parents to soft tissue injuries. Delays in the initial treatment might be due to a large number of the referred patients living some distance from the clinic, the absence of an after-hours dentist, unawareness of the after-hours service, giving a low priority to dental injuries, and not considering emergency management of dental injuries a priority.

According to a previous study, the most common type of dento-alveolar trauma was hard dental tissue and pulp injuries in permanent dentition and supporting or hard dental tissue and pulp injuries in primary dentition (28). A literature search revealed no relationship between soft tissue injuries and dento-alveolar trauma. In our study, we observed soft tissue injuries more frequently in injuries to the supporting tissues $(64.4 \%)$ than injuries to the hard dental tissues and pulp (22.2\%). With regard to tooth injury mechanisms, one study found that a lowvelocity direct force, usually cushioned by the lips or cheek, was responsible for damage caused to the supporting structures $(24,26)$. Another study found that the presence of cartilage in the skeletal system in children and a greenstick fracture pattern may help both soft and hard tissues absorb a traumatic force (29). In this study, high supporting tissue injury rates was responsible for the high incidence of soft tissue injuries in primary dentition.

Although soft tissue injuries are self-healing, inadequate primary treatment may result in unsightly scarring. It is important to educate primary health care providers on the proper emergency management of soft tissue injuries to reduce the long-term consequences and to educate parents about the necessity of seeking immediate treatment. Future studies of the treatment of such injuries and the patients' prognoses might be useful to provide additional information on the consequences and management of soft tissue trauma.

\section{Conclusion}

Soft tissue injuries are occasionally seen in dentoalveolar traumas. The severity, type, and localization of the trauma seem to be more important factors than gender and age in the occurrence of soft tissue injuries. Soft tissue injuries were frequently seen in the maxillary region, and they were accompanied by supporting tissue injuries. The most common soft tissue injuries were lacerations, and abrasions were common in perioral tissues.

\section{Ethics}

Ethics Committee Approval: The study protocol was approved by the Ethics Committee of the Atatürk University Faculty of Medicine (reference number: 2013/40).

Informed Consent: The written informed consent was obtained from all patients.

Peer-review: Externally peer-reviewed. 


\section{Authorship Contributions}

Concept: F.Ş., H.Ş, Design: H.Ş., F.Ş., Data Collection or Processing: F.Ş., Analysis or Interpretation: H.Ş., Literature Search: H.Ş., Writing: F.Ş.

Conflict of Interest: No conflict of interest was declared by the authors.

Financial Disclosure: The authors declared that this study received no financial support.

\section{References}

1. Petersson EE, Andersson L, Sörensen S. Traumatic oral vs nonoral injuries. Swed Dent J 1997; 21: 55-68.

2. Nair KB, Paul G. Incidence and aetiology of fractures of the faciomaxillary skeleton in Trivandrum: a retrospective study. Br J Oral Maxillofac Surg 1986; 24: 40-3.

3. Osunde OD, Amole IO, Ver-or N, Akhiwu BI, Adebola RA, Iyogun CA, et al. Pediatric maxillofacial injuries at a Nigerian teaching hospital: a three-year review. Niger J Clin Pract 2013; 16: 149-54.

4. Díaz JA, Bustos L, Brandt AC, Fernández BE. Dental injuries among children and adolescents aged $1-15$ years attending to public hospital in Temuco, Chile. Dent Traumatol 2010; 26: 25461.

5. Al-Jundi SH. The importance of soft tissue examination in traumatic dental injuries: a case report. Dent Traumatol 2010; 26: 509-11.

6. Kotecha S, Scannell J, Monaghan A, Williams RW. A four year retrospective study of 1,062 patients presenting with maxillofacial emergencies at a specialist paediatric hospital. $\mathrm{Br}$ J Oral Maxillofac Surg 2008; 46: 293-6.

7. Andreasen JO, Bakland LK, Flores MT, Andreasen FM, Andersson L. Classification of dental injuries. In: Andreasen JO, Bakland LK, Flores MT, Andreasen FM, Andersson L, eds. Traumatic dental injuries : a manual. 3rd ed. Oxford, Wiley-Blackwell, 2011; pp 16-77.

8. O'Neil DW, Clark MV, Lowe JW, Harrington MS. Oral trauma in children: a hospital survey. Oral Surg Oral Med Oral Pathol 1989; 68: 691-6.

9. Gassner R, Bösch R, Tuli T, Emshoff R. Prevalence of dental trauma in 6000 patients with facial injuries: implications for prevention. Oral Surg Oral Med Oral Pathol Oral Radiol Endod 1999; 87: 27-33.

10. Valero C, Javierre E, García-Aznar JM, Menzel A, Gómez-Benito MJ. Challenges in the Modeling of Wound Healing Mechanisms in Soft Biological Tissues. Ann Biomed Eng 2014; 43: 1654-65.

11. Delos D, Maak TG, Rodeo SA. Muscle injuries in athletes: enhancing recovery through scientific understanding and novel therapies. Sports Health 2013; 5: 346-52.

12. Glendor U. Epidemiology of traumatic dental injuries--a 12 year review of the literature. Dent Traumatol 2008; 24: 603-11.

13. Lam R, Abbott P, Lloyd C, Lloyd C, Kruger E, Tennant M. Dental trauma in an Australian rural centre. Dent Traumatol 2008; 24: 663-70.
14. Gassner R, Tuli T, Hächl O, Moreira R, Ulmer H. Craniomaxillofacial trauma in children: a review of 3,385 cases with 6,060 injuries in 10 years. J Oral Maxillofac Surg 2004; 62: 399-407.

15. Gassner R, Tuli T, Hächl O, Rudisch A, Ulmer H. Cranio-maxillofacial trauma: a 10 year review of 9,543 cases with 21,067 injuries. J Craniomaxillofac Surg 2003; 31: 51-61.

16. Flores MT. Traumatic injuries in the primary dentition. Dent Traumatol 2002; 18: 287-98.

17. Onetto JE, Flores MT, Garbarino ML. Dental trauma in children and adolescents in Valparaiso, Chile. Endod Dent Traumatol 1994; 10: 223-7.

18. Okoje VN, Alonge TO, Oluteye OA, Denloye OO. Changing pattern of pediatric maxillofacial injuries at the Accident and Emergency Department of the University Teaching Hospital, Ibadan--a fouryear experience. Prehosp Disaster Med 2010; 25: 68-71.

19. Kim DB, Sacapano M, Hardesty RA. Facial fractures in children. West J Med 1997; 167: 100.

20. Vuletić M, Škaričić J, Batinjan G, Trampuš Z, Čuković Bagić I, Jurić $H$. A retrospective study on traumatic dental and soft-tissue injuries in preschool children in Zagreb, Croatia. Bosn J Basic Med Sci 2014; 14: 12-5.

21. Erikson EH, Erikson JM. The life cycle completed. Extended / with new chapters on the ninth stage of development by Joan M. Erikson. ed. New York: W.W. Norton, 1997.

22. Andersson L, Andreasen JO. Soft tissue injuries. In: Andreasen JO, Andreasen FM, Andersson L, eds. Textbook and color atlas of traumatic injuries to the teeth. 4th ed. Oxford: Blackwell Munksgaard; 2007; p. 577-97.

23. Eyuboglu O, Yilmaz Y, Zehir C, Sahin H. A 6-year investigation into types of dental trauma treated in a paediatric dentistry clinic in Eastern Anatolia region, Turkey. Dent Traumatol 2009; 25: 110-4.

24. Maréchaux SC. Chin trauma as a cause of primary molar fracture: report of case. ASDC J Dent Child 1985; 52: 452-4.

25. Yang RT, Li Z, Li ZB. Maxillofacial injuries in infants and preschools: a 2.5-year study. J Craniofac Surg 2014; 25: 964-7.

26. Andreasen JO. Etiology and pathogenesis of traumatic dental injuries. A clinical study of 1,298 cases. Scand J Dent Res 1970; 78: 329-42.

27. Thompson EC, Porter JM, Fernandez LG. Penetrating neck trauma: an overview of management. J Oral Maxillofac Surg 2002; 60: 918-23.

28. Glendor U, Marcenes W, Andreasen JO. Classification, Epidemiology and Etiology. In: Andreasen JO, Andreasen FM, Andersson L, eds. Textbook and color atlas of traumatic injuries to the teeth. 4th ed. Oxford: Blackwell Munksgaard; 2007; p. 217-54.

29. Pinkham JR. The dynamics of change, ed 4. Pediatric dentistry: infancy through adolescence. Philadelphia, PA: Elsevier Saunders, 2005. 